\section{Rizal Khadafi}

Magister Ilmu Pemerintahan Universitas

Muhammadiyah Yogyakarta

Email: dafinasution@yahoo.co.id

\section{Dyah Mutiarin}

Dosen Magister IImuPemerintahan Universitas

Muhammadiyah Yogyakarta

Email: mutiarin@yahoo.com
Efektivitas Program Bantuan Keuangan Khusus

Dalam Mengentaskan Kemiskinan di Kabupaten

\section{Gunungkidul}

https://doi.org/10.18196/jgpp.4280

\begin{abstract}
ABSTRAK
Kabupaten Gunungkidul merupakan salah satu daerah yang berada dalam wilayah administratif Provinsi Daerah Istimewa Yogyakarta. Dalam hal kemiskinan Kabupaten Gunungkidul merupakan daerah termiskin diantara lima Kabupaten/Kota lainnya. Angka kemiskinan, angka buta huruf, angka perceraian, dan angka putus sekolah yang tinggi, semakin memperkukuh status Kabupaten Gunungkidul sebagai Kabupaten termiskin di DIY.Pengentasan kemiskinan di Kabupaten Gunungkidul pasca reformasi ternyata menunnjukkan hasil yang cenderung statis. Sekalipun dalam hal ini, Pemerintah Pusat, Pemerintah Provinsi DIY, maupun Pemerintah Kabupaten Gunungkidul sendiri telah melakukan berbagai upaya dalam mengentaskan kemiskinan di Kabupaten Gunungkidul. Secara umum APBD kabupaten Gunungkidul masih sangat bergantung pada sektor pertanian. Angka penduduk miskin masih tinggi, begitu juga dengan angka buta huruf yang masih menempati urutan kelima diantara Kabupaten lain yang berada dalam wilayah administratif Provinsi Daerah Istimewa Yogyakarta.Dalam upaya mengentaskan kemiskinan di Kabupaten Gunungkidul kedepannya, Pemerintah Kabupaten Gunungkidul harus segera membenahi diri dengan cara menyediakan data yang lengkap, serta konsisten dengan program pengentasan kemiskinan yang berkesinambungan dan anggaran yang pro terhadap pengentasan kemiskinan. Kreatifitas dan inovasi dalam membuat kebijakan sangat mutlak dibutuhkan, hal ini dikarenakan Kabupaten Gunungkidul terbilang memiliki potensi alam yang luar biasa.Memaksimalkan lahan yang tersedia, mengelola potensi wisata, serta meningkatkan kualitas sumber daya manusia adalah hal yang paling realistis untuk dilakukan saat ini.Mengingat, bahwa Kabupaten Gunungkidul merupakan Kabupaten terluas di DIY dengan potensi alam yang luar biasa, sudah semestinya masalah kemiskinan di Gunugkidul dapat segera diatasi.
\end{abstract}

Kata kunci: Pemerintah Kabupaten Gunungkidul, PengentasanKemiskinan, Inovasi

\title{
PENDAhUluaN
}

\section{LATAR BELAKANG MASALAH}

Salah satu tujuan dari kemerdekaan Indonesia seperti yang tercantum dalam pembukaan Undang-undang Dasar 1945 adalah mewujudkan masyarakat merdeka, bersatu, berdaulat, adil dan makmur. Namun, seiring berjalannya waktu cita-cita mulia kemerdekaan khususnya dalam hal kemakmuran belum sepenuhnya terwujud dengan baik, menurut data yang yang dirilis Badan Pusat Statistik (BPS) per September 2014 angka 
328 kemiskinan di Indonesia masih berada di angka 27,72 juta orang atau sekitar 10,96 persen dari total jumlah penduduk Indonesia. Angka ini sebenarnya mengalami penurunan sebanyak 0,53 juta orang dibandingkan dengan priode Maret 2014 yaitu sebanyak 28,28 juta orang dengan persentase 11,25 persen.

Menurut data yang dirilis Badan Pusat Statistik (BPS) sebelumnya, selama periode September 2013 - Maret 2014 jumlah penduduk miskin daerah perkotaan turun sebanyak 0,17 juta dari 10,68 juta pada September 2013 menjadi 10,51 juta pada Maret 2014. Sementara itu, di daerah pedesaan turun sebanyak 0,15 juta orang dari 17,92 orang pada September 2013 menjadi 17,77 juta pada Maret 2014. Persentase penduduk miskin di daerah perkotaan September 2013 sebesar 8,55 persen turun menjadi 8,34 persen pada Maret 2014 sementara persentase penduduk miskin di daerah perdesaan turun 14,37 persen pada September 2013 menjadi 14,17 persen pada Maret 2014.

Kemiskinan di Provinsi Daerah Istimewa Yogyakarta menurut Badan Pusat Statistik Daerah Istimewa Yogyakarta (BPS DIY) masih berada di angka 270.110 pada Tahun 2012 dengan persentase sebesar 15,88 persen, angka ini kemudian mengalami penurunan pada Tahun 2013 dengan persentase sebesar 15,03 persen. Sekalipun DIY merupakan ikon pendidikan dan wisata, namun menurut data yang dirilis BPS per September 2014 DIY merupakan provinsi termiskin se-Jawa, data ini tentu sangat mengejutkan berbagai pihak mengingat pertumbuhan ekonomi di DIY pada Tahun 2013 masih berada di sekitaran angka 4,5-5,5 persen, meski melambat angka ini masih 
tinggi dibandingkan dengan pertumbuhan ekonomi provinsi lain. Menariknya adalah, sekalipun salah satu faktor mata rantai kemiskinan adalah tingkat pendidikan yang rendah, hal ini sepertinya tidak berlaku bagi provinsi DIY mengingat DIY merupakan provinsi dengan Indeks Pembangunan Manusia (IPM) tertinggi kedua di Indonesia setelah DKI Jakarta (BPS, 2013).

Tabel 1.2

Garis Kemiskinan, Indeks Kedalaman Kemiskinan (P1), dan Indeks Keparahan Kemiskinan (P2) Menurut Provinsi Se - Jawa Per September 2014

\begin{tabular}{|c|c|c|c|c|c|c|c|c|c|}
\hline \multirow{2}{*}{ Propinsi } & \multicolumn{3}{|c|}{$\begin{array}{c}\text { Garis Kemiskinan } \\
\text { (Rp/kapita/Bulan) }\end{array}$} & \multicolumn{3}{|c|}{ K1 (\%) } & \multicolumn{3}{c|}{ P2 (\%) } \\
\cline { 2 - 11 } & Kota & Desa & $\begin{array}{c}\text { Kota } \\
\text { Desa }\end{array}$ & Kota & Desa & $\begin{array}{c}\text { Kota } \\
\text { Desa }\end{array}$ & Kota & Desa $\begin{array}{c}\text { Kota } \\
+ \\
\text { Desa }\end{array}$ \\
\hline Lampung & 350024 & 307818 & 318822 & 1,90 & 2,43 & 2,30 & 0,51 & 0,58 & 0,56 \\
\hline $\begin{array}{c}\text { DKI } \\
\text { Jakarta }\end{array}$ & 459560 & 0 & 459560 & 0,60 & 0,00 & 0,60 & 0,13 & 0,00 & 0,13 \\
\hline $\begin{array}{c}\text { Jawa } \\
\text { Barat }\end{array}$ & 294700 & 285076 & 291474 & 1,31 & 1,55 & 1,39 & 0,32 & 0,35 & 0,33 \\
\hline $\begin{array}{c}\text { Banten } \\
\text { Jawa } \\
\text { Tengah }\end{array}$ & 324902 & 296241 & 315819 & 0,65 & 1,08 & 0,79 & 0,13 & 0,27 & 0,18 \\
\hline $\begin{array}{c}\text { DI } \\
\text { Yogyakart } \\
\text { a }\end{array}$ & $\mathbf{3 3 3 5 6 1}$ & $\mathbf{2 9 6 4 2 9}$ & $\mathbf{3 2 1 0 5 6}$ & $\mathbf{2 , 0 3}$ & $\mathbf{2 , 9 8}$ & $\mathbf{2 , 3 5}$ & $\mathbf{0 , 5 2}$ & $\mathbf{0 , 7 9}$ & $\mathbf{0 , 6 1}$ \\
\hline $\begin{array}{c}\text { Jawa } \\
\text { Timur }\end{array}$ & 293391 & 286798 & 289945 & 1,24 & $\mathbf{2 , 4 2}$ & 1,86 & 0,31 & 0,59 & 0,45 \\
\hline
\end{tabular}

Sumber: Badan Pusat Statistik

Kabupaten Gunung Kidul salah satu daerah termiskin di Indonesia, selain itu pada dasawarsa 80'an Kabupaten ini terkenal dengan bencana kekeringan dan bahan makanan gaplek (singkong kering yang dijemur), daerah dengan penyuplai buruh rumah tangga di Ibu Kota Jakarta. Hal semacam ini lah yang menjadikan Kabupaten Gunung Kidul dikelan sebagai Kabupaten termiskin, tetapi seiring 
331 berjalannya waktu imej tersebut perlahan mulai berkurang tetapi tidak menutup kemungkinan masih banyaknya permasalahan di Kabupaten Gunung Kidul.

Adapun beberapa permasalahan di Kabupaten Gunung Kidul adalah sebagai berikut: Pertama, masalah kekeringan dan masalah air bersih adalah permasalahan klasik yang tak kunjung selesai di Gunungkidul. Menurut data Badan Pusat Statistik Gunungkidul (BPS:2014), Pemerintah Kabupaten Gunungkidul sebenarnya telah menerapkan lima pola penanganan untuk mengatasi persoalan air bersih. Pertama, membuat jaringan seperti yang telah dilakukan oleh Perusahaan Daerah Air Minum, yang telah mampu membangun puluhan ribu sambungan rumah. Kedua, dengan cara swadaya mandiri, yakni kerja sama antara pemerintah, masyarakat, dan swasta dalam memanfaatkan sumber air yang ada. Kemudian membangun bak-bak penampungan air di setiap rumah.Keempat, melakukan pengiriman air bersih dengan menggunakan mobil tangki ke kawasan yang kekurangan air bersih pada musim kemarau. Kelima, dengan gerakan penghijauan, diharapkan akan menambah sumber air.

Kedua, tingginya kasus perceraian yang terjadi di Gunungkidul, dan sebagian besar kasus perceraian di Gunungkidul berlatar belakang masalah ekonomi keluarga. Tercatat selama tahun 2013 terdapat 1.519 kasus, dan Tahun 2014 meningkat menjadi 1.700 kasus (Pengadilan Agama Gunungkidul: 2014).Ketiga, tinginya angka kematian akibat bunuh diri di Gunungkidul , pada tahun 2012-2014, terjadi masing-masing 40 kasus pada Tahun 2012, Tahun 2013 terdapat 29 kasus, sementara pada per Oktober 2014 terdapat 17 
kasus bunuh diri, mayoritas dengan cara gantung diri (Polres Gunungkidul: 2014 dikutip oleh Berita Satu Edisi: Minggu 5 Oktober 2014).

Keempat, Gunungkidul adalah salah satu Kabupaten di Provinsi Daerah Istimewa Yogyakarta yang memiliki penduduk buta aksara terbanyak, umumnya mereka terkonsentrasi di wailayah-wilayah yang susah dijangkau. Karena itu salah satu fokus pembangunan pendidikan Pemerintah Daerah Kabupaten Gunungkidul adalah memperluas akses pendidikan dan percepatan pentuntasan buta aksara.Kelima, Masalah kemiskinan di Gunungkidul masih menjadi topik paling penting untuk dibahas karena adanya saling keterkaitan yang sangat erat antara masalah-masalah yang telah di jelaskan sebelumnya dengan masalah kemiskinan di Gunungkidul. Menariknya masalah kemiskinan di Gunungkidul masih didominasi daerah pedesaan.

\section{Gambar 1.1}

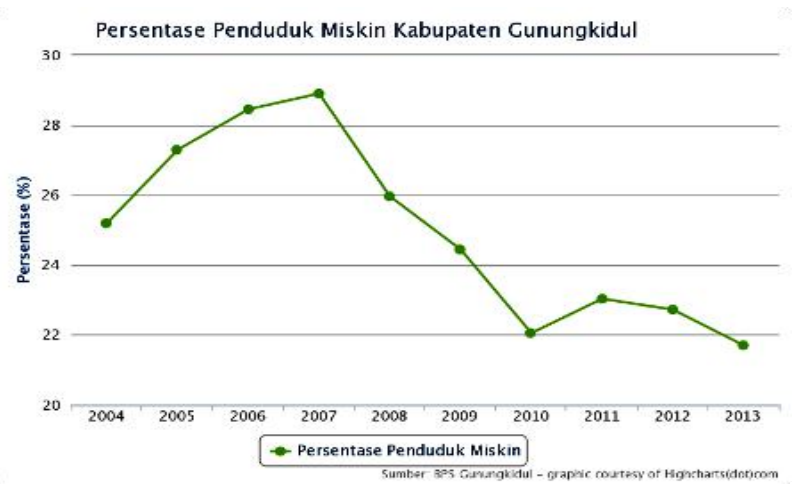




\section{Tabel 1.5}

Jumlah Penduduk Miskin dan Garis Kemiskinan Menurut Kabupaten/Kota di D.I. Yogyakarta

\begin{tabular}{ccccccc}
\hline \multicolumn{2}{c}{2012} & \multicolumn{5}{c}{2013} \\
\hline $\begin{array}{c}\text { Kabupaten / } \\
\text { Kota }\end{array}$ & $\begin{array}{c}\text { Garis } \\
\text { Kemiskin } \\
\text { an }\end{array}$ & $\begin{array}{c}\text { Jumla } \\
\text { h } \\
\text { Total }\end{array}$ & $\begin{array}{c}\text { Garis } \\
\text { Kemiskin } \\
\text { an }\end{array}$ & $\begin{array}{c}\text { Jumlah } \\
\text { Total }\end{array}$ & $\%$ \\
Bantul & 277792 & 159,2 & 16,97 & 292639 & 156,6 & 16,48 \\
Gunungkidu & 228745 & 157,8 & 22,71 & 238056 & 152,4 & 21,70 \\
I & & & & & & \\
Kulonprogo & 250854 & 93,2 & 23,31 & 259945 & 86,5 & 21,39 \\
Sleman & 281644 & 118,2 & 10,44 & 297170 & 110,8 & 9,68 \\
\hline Yogyakarta & 333232 & 37,4 & 9,38 & 353602 & 35,6 & 8,82 \\
DIY & 270110 & 565,7 & 15,88 & 303843 & 541,9 & 15,03 \\
\hline
\end{tabular}

Sumber: Badan Pusat Statistik

Kabupaten Gunungkidul satu-satunya kabupaten di DIY yang masuk program pengentasan kemiskinan Badan Perencanaan Pembangunan Nasional (Bappenas) Tahun 2013-2014. Masuknya Gunungkidul dalam program Bappenas karena, hingga kini Gunungkidul masuk dalam daerah lokasi rencana perluasan pengentasan kemiskinan Indonesia. Koordinator Program Pro Poor Planning, Budgeting and Monitoring (P3BM) Bappenas La Ega mengatakan, Kulon Progo dan Gunungkidul masuk dalam kategori pengentasan kemiskinan Bappenas, namun angka kemiskinan di Gunungkidul lebih tinggi dibanding Kulon Progo (Dikutip dari: Sorot Gunungkidul: Edisi Kamis 02 Mei 2013).

Masalah kekeringan dan rendahnya tingkat pendidikan, merupakan akar kemiskinan di Gunungkidul, kemudian masalah 
kemiskinan memicu masalah angka perceraian yang tinggi, tingkat bunuh diri yang tinggi, dan masalah-masalah sosial lainnya. Sekalipun dalam laporan yang dikeluarkan oleh Pengadilan Agama Gunungkidul mayoritas perceraian dipicu oleh kekerasan dalam rumah tangga (KDRT), namun yang menarik laporan yang dikeluarkan oleh Kepolisian Resor Gunungkidul penyebab utama kekerasan dalam rumah tangga (KDRT) mayoritas berlatar belakang masalah ekonomi.

Dalam hal ini penulis tertarik mengangkat tema yang lebih spesifik lagi, yaitu efektivitas program bantuan keuangan khusus (BKK) yang dicanangkan oleh Pemerintah Provinsi Daerah Istimewa Yogyakarta dalam mengentaskan kemiskinan di DIY khususnya di Kabupaten Gunugkidul. Lebih lanjut penelitian ini akan mengkaji lebih dalam tentang bagaimana perkembangan, permasalahan, serta efek bantuan keuangan khusus tersebut terhadap pemenuhan hak dasar, peningkatan taraf hidup masyarakat serta daya saing daerah Gunungkidul dalam berbagai aspek kehidupan bermasyarakat, berbangsa dan bernegara.

Berdasarkan fenomena yang telah disebutkan maka penulis ingin fokus tentangefektivitas program bantuan keuangan khusus (BKK) daerah dalam mengentaskan kemiskinan di Kabupaten Gunungkidul, dan faktor-faktor apa saja yang mempengaruhi efektivitas program bantuan keuangan khusus dalam mengentaskan kemiskiknan di Kabupaten Gunung Kidul.

\section{TINJAUAN PUSTAKA}

\section{Efektivitas Program Bantuan Keuangan Khusus}


334 Kata efektiv berasal dari bahasa Inggris yaitu "Effective" yang berarti berhasil atau sesuatu yang dilakukan berhasil dengan baik.Kamus ilmiah populer mendefinisikan efetivitas sebagai ketepatan penggunaan, hasil guna atau menunjang tujuan.Menurut Effendy (2003) efektivitas adalah komunikasi yang prosesnya mencapai tujuan yang direncanakan sesuai dengan biaya yang dianggarkan, waktu yang ditetapkan dan jumlah personil yang ditentukan.Pengertian efektivitas menurut Hadayaningrat (1996) dalam buku Azas-azas Organisasi Manajemen adalah pengukuran dalam arti tercapainya sasaran atau tujuan yang telah ditentukan sebelumnya. Pendapat Hadayaningrat mengartikan efektivitas bisa diartikan sebagai suatu pengukuran akan tercapainya tujuan yang telah direncanakan sebelumnya secara matang.

Budiani (2007:53) menyatakan bahwa untuk mengukur efektivitas suatu program dapat dilakukan dengan menggunakan variabel-variabel sebagai berikut :

1) Ketepatan sasaran program

Yaitu sejauhmana peserta program tepat dengan sasaran yang sudah ditentukan sebelumnya.

2) Sosialisasi program

Yaitu kemampuan penyelenggara program dalam melakukan sosialisasi program sehingga informasi mengenai pelaksanaan program dapat tersampaikan kepada masyarakat pada umumnya dan sasaran peserta program pada khususnya.

3) Tujuan program 
Yaitu sejauhmana kesesuaian antara hasil pelaksanaan program dengan tujuan program yang telah ditetapkan sebelumnya.

4) Pemantuan program

Yaitu kegiatan yang dilakukan setelah dilaksanakannya program sebagai bentuk perhatian kepada peserta program.

Efektivitas program dapat dijalankan dengan kemampuan operasional dalam melaksanakan program-program kerja yang sesuai dengan tujuan yang telah ditetapkan sebelumnya, secara komprehensif, efektivitas dapat diartikan sebagai tingkat kemampuan suatu lembaga atau organisasi untuk dapat melaksanakan semua tugas-tugas pokoknya atau untuk mencapai sasaran yang telah ditentukan sebelumnya (Cambel, 1989:47).

Kaitannya dengan program bantuan keuangan khusus (BKK), maka yang dimaksud dengan efektivitas di sini adalah dengan mengukur indikator keberhasilan pelaksanaan program bantuan keuangan khusus yaitu tepat sasaran penerima manfaat, tepat jumlah, tepat waktu, tepat administrasi, dan tepat penggunaanya.

1) Tepat Sasaran Penerima Bantuan: Bantuan keuangan khusus hanya diberikan kepada rumah tangga sasaran (RTS) yang telah memenuhi persyaratan dan telah lolos verifikasi sesuai dengan petunjuk pengelolaan bantuan keuangan khusus dalam mengentaskan kemiskinan. Sesuai dengan Keputusan Gubernur Daerah Istimewa Yogyakarta jumlah penerima Bantuan keuangan khusus untuk Kabupaten Gunungkidul untuk tahun 2014 adalah sebanyak 8.335 RTS. 
2) Tepat Jumlah: Jumlah uang yang diterima oleh kelompok rumah tangga sasaran (RTS) dari program bantuan keuangan khusus (BKK) adalah sebesar 1.000.000,00 (satu juta rupiah).

3) Tepat Waktu: Waktu pelaksanaan Distribusi bantuan keuangan khusus (BKK) adalah sejak pemerintah daerah Kabupaten menerima pencairan dana dari pemerintah Provinsi dan menuangkannya dalam bentuk peraturan daerah (PERDA).

4) Tepat Administrasi: Terpenuhinya persyaratan Administrasi secara benar dan tepat waktu, sesuai dengan pedoman pengelolaan bantuan keuangan khusus dalam mengentaskan kemiskinan.

5) Tepat Penggunaan: Penggunaan dana program bantuan keuangan khusus, dipergunakan sesuai dengan yang tertera di proposal pengajuan yang diajukan oleh kelompok rumah tangga sasaran (RTS), yaitu bersifat produktif dan berkesinambungan.

\section{Pengentasan Kemiskinan}

Secara etimologis kemiskinan berasal dari kata miskin yang artinya tidak berharta benda dan serba kekurangan. Departemen Sosial dan Biro Pusat Statistik, mendefinisikan kemiskinan sebagai ketidakmampuan individu dalam memenuhi kebutuhan dasar minimal untuk hidup layak (BPS dan Depsos: 2002). Dalam konteks politik, John Friedman (1979) dalam Dorojatun (1986) mendefinisikan kemiskinan sebagai suatu ketidaksamaan kesempatan dalam mengakumulasikan basis kekuatan sosial.Frank Ellis dalam 
Suharto (2005) menyatakan bahwa kemiskinan memiliki berbagai dimensi yang menyangkut aspek ekonomi, politik dan sosial-psikologis. Orang disebut miskin jika dalam kadar tertentu sumber daya ekonomi yang mereka miliki di bawah target atau patokan yang telah ditentukan.

Menurut Badan Pusat Statistik (2014) penetapan perhitungan garis kemiskinan dalam masyarakat adalah masyarakat yang berpenghasilan dibawah US $\$ 1,7$ per orang per hari. Penetapan angka US\$1,7 per orang per hari tersebut berasal dari perhitungan garis kemiskinan yang mencakup kebutuhan makanan dan non makanan. Untuk kebutuhan minimum makanan digunakan patokan 2.100 kilo kalori per kapita per hari.Sedangkan untuk pengeluaran kebutuhan minimum bukan makanan meliputi pengeluaran untuk perumahan, pendidikan, dan kesehatan.Sedangkan ukuran menurut World Bank menetapkan standar kemiskinan berdasarkan pendapatan per kapita.Penduduk yang pendapatan per kapitanya kurang dari sepertiga rata-rata pendapatan perkapita nasional. Dalam konteks tersebut, maka ukuran kemiskinan menurut World Bank adalah USD \$2 per orang per hari.

Adapun faktor-faktor Penyebab Kemiskinan menurut Sharp dalam Kuncoro (2000) terdapat tiga faktor penyebab kemiskinan jika dipandang dari sisi ekonomi.

1. Pertama, kemiskinan muncul karena adanya ketidaksamaan pola kepemilikan sumberdaya yang menimbulkan distribusi pendapatan yang timpang. Penduduk miskin hanya memiliki sumberdaya yang terbatas dan kualitasnya rendah. 

sumberdaya manusia. Kualitas sumberdaya manusia yang rendah berarti produktifitanya rendah, yang pada gilirannya upahnya rendah. Rendahnya kualitas sumberdaya manusia ini karena rendahnya pendidikan, nasib yang kurang beruntung, adanya diskriminasi atau keturunan.

3. Kemiskinan muncul karena perbedaan akses terhadap modal.

\section{Kerangka Pikir}

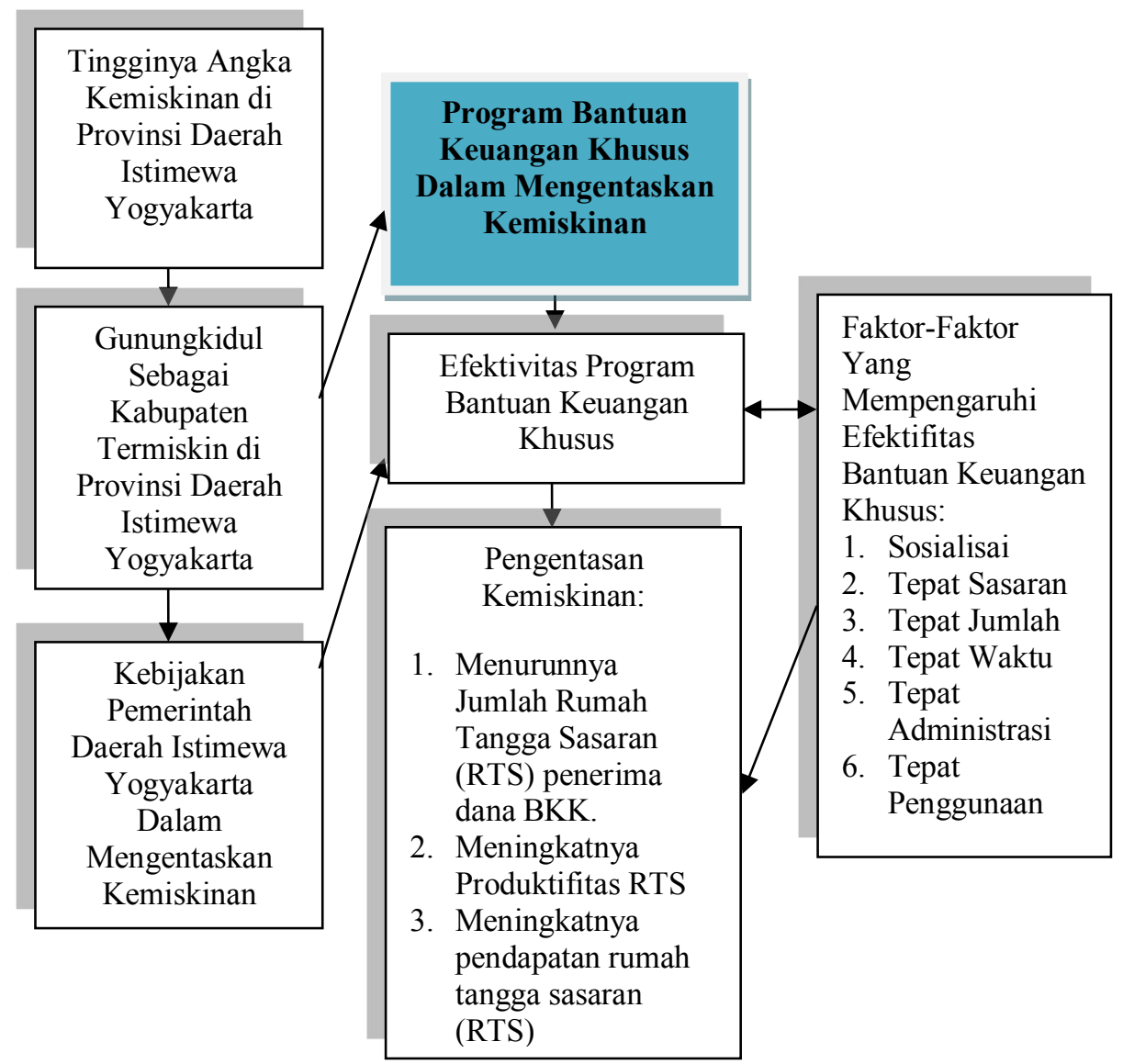




\section{METODEPENELITIAN}

Penelitian ini menggunakan metode kualitatif.Lokasi penelitian di lingkungan kerja Pemerintah Daerah Kabupaten Gunungkidul yaitu Tim Koordinasi Penanggulangan Kemiskinan Daerah (TKPKD) KabupatenGunungkidul.Pada penelitian ini teknik penentuan sampel yang digunakan adalah Purposive Sampling.Teknik pengambilan sampel ini dipakai dengan tujuan untuk lebih memenuhi keterwakilan sampel yang diambil terhadap populasi.Sedangkan narasumber dalam penelitian ini adalah para pihak-pihak yang terkait dan terlibat langsung dalam pelaksanaan program bantuan keuangan khusus di Kabupaten Gunungkidul. Narasumber dari penelitian ini berasal dari Tim Koordinasi Penanggulangan Kemiskinan Daerah (TKPKD) Kabupaten Gunungkidul dan rumah tangga sasaran (RTS), yang meliputi:

a) Kepala BAPEDA Gunungkidul

b) Kepala Dinas Pendapatan Pengelolaan Keuangan dan Aset Daerah (DPPKAD) Kabupaten Gunungkidul

c) Kepala Badan pelaksana penyuluhan dan ketahanan pangan (BP2KP) Kabupaten Gunungkidul

d) Rumah tangga sasaran (RTS) penerima program bantuan keuangan khusus Kabupaten Gunungkidul.

\section{HASIL DAN PEMBAHASAN}

\section{Sosialisasi}

Sosialisasi program pada dasarnya adalah penyebarluasan informasi baik itu program, kebijakan, ataupun peraturan dari pihak pembuat 
310 atau pemilik program, kebijakan, dan peraturan kepada pihak-pihak lain yang menjadi pelaksana maupun yang menjadi sasaran dari program tersebut.Isi informasi yang disebarluaskan bermacam-macam tergantung pada tujuan program. Dalam kaitannya dengan sosialisasi program Bantuan Keuangan Khusus (BKK) di Kabupaten Gunungkidul, ada dua tahapan sosialisasi yang harus dilalui, pertama, sosialisasi tingkat kabupaten yaitu: sosialisasi dan pembekalan kepada SKPD dan camat, sosialisasi dan pembekalan kepada Kepala Desa dan sosialisasi dan pembekalan kepada pendamping.Kedua, sosialisasi tingkat desa yaitu sosialisasi oleh Kepala Desa kepada Rumah Tangga Sasaran (RTS) (Peraturan Bupati Gunungkidul Nomor 5 tahun 2014).

Dari tabel diatas dapat dilihat bahwa tahapan sosialisasi meliputi dua hal.Pertama, pelaksanaan kegiatan sosialisasi di tingkat Kabupaten, yaitu sosialisasi kepada SKPD dan camat, kepala desa dan sosialisasi kepada pendamping.Kedua, pelaksanaan kegiatan sosialisasi di tingkat desa, untuk membentuk Kelompok perlu diawali dengan sosialisasi oleh Kepala Desa kepada Rumah Tangga Sasaran (RTS).Kegiatan sosialisasi dilakukan di tingkat desa dengan difasilitasi oleh Pemerintah Desa dibantu oleh Pendamping Lapangan, hal-hal yang perlu disosialisasikan adalah Arah program BKK maupun tujuan-tujuan yang ingin dicapai dan konsep kelompok.Menurut Claar dalam Nasution (1990:7) Penyuluhan atau sosialisasi merupakan jenis khusus pendidikan pemecahan masalah (problem solving) yang berorientasi pada tindakan, yang mengajarkan sesuatu, mendemonstrasikan, dan memotivasi, tapi tidak melakukan 
pengaturan (regulating) dan juga tidak melaksanakan program yang non-edukatif.

Sosialisasi di tingkat desa juga merupakan sarana bagi Rumah Tangga Sasaran (RTS) penerima dana bantuan keuangan khusus, untuk bertanya dan memperjelas mengenai hal-hal yang berkaitan dengan program ini. Dalam proses ini ada tiga hal yang menjadi tujuan utama dari proses sosialisai. Ketiga hal tersebut adalah pembentukan kelompok, kemudian dijelaskan mengenai arah program dan tujuan yang khendak dicapai serta diakhiri dengan memperjelas konsep Rumah Tangga Sasaran (RTS) mengenai penggunaan dana.

Budiani (2007:53) menyatakan bahwa untuk mengukur efektivitas suatu program salah satunya dapat dilakukan dengan menggunakan variabel sosialisai program.Sosialisai program yaitu kemampuan penyelenggara program dalam melakukan sosialisasi program sehingga informasi mengenai pelaksanaan program dapat tersampaikan kepada masyarakat pada umumnya dan sasaran peserta program pada khususnya. Pendamping lapangan yang terlibat langsung mendampingi perangkat desa dalam proses sosialisasi, bertugas menjelaskan secara detail mengenai program BKK serta mekanisme yang harus dilalui RTS pra dan pasca pencairan dana program.Proses sosialisasi di tingkat desa hanya mengukuhkan apa yang sudah tertuang di dalam PERBUB dan kehadiran pendamping lapangan untuk membantu kepala desa atau perangkat desa sekaligus 
310 untuk mengenal lebih dekat dengan kelompok yang akan didampinginya.

\section{Gambar V.1}

Sosialisasi Program

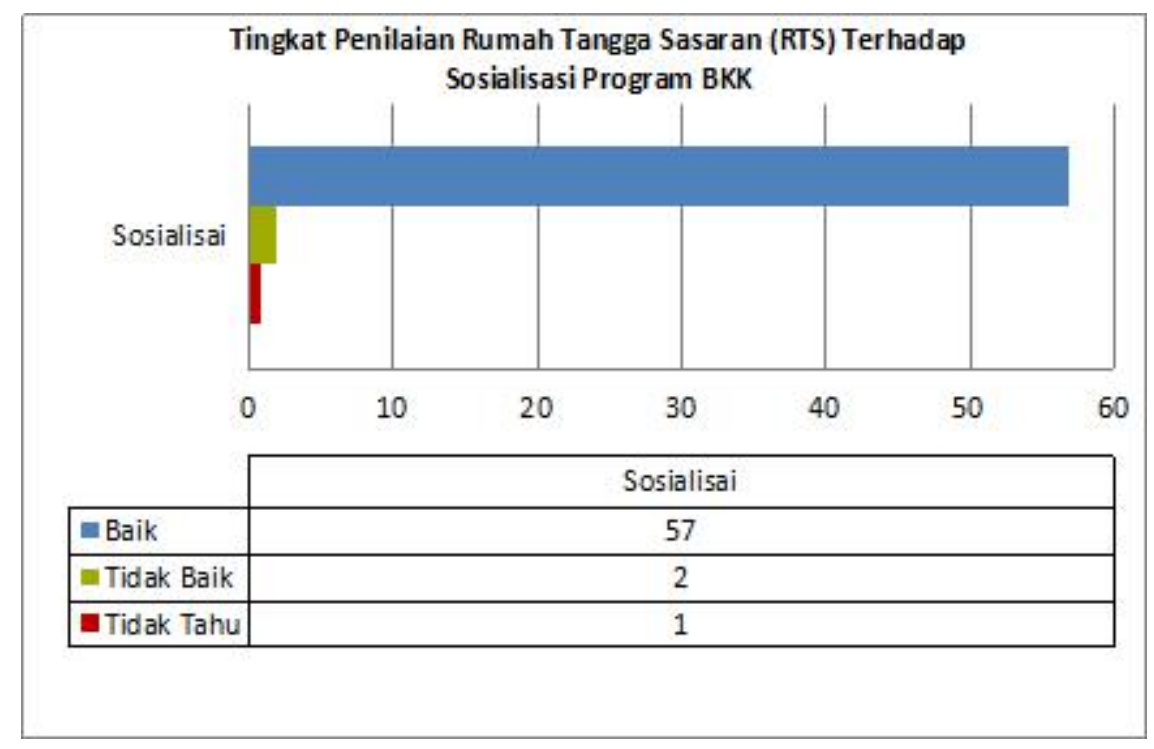

\section{Sumber: Data Primer Tahun 2015}

Dari grafik di atas dapat disimpulkan bahwa bahwa penilaian rumah tangga sasaran terhadap sosialisasi program Bantuan Keuangan Khusus (BKK) cenderung baik, dari 60 orang yang menjadi narasumber, 57 orang mengaku sosialisasi berjalan baik, 2 orang merasa tidak baik, dan 1 orang menjawab tidak tahu.Merujuk pada pendapat Budiani (2007:53) bahwa variabel sosialisasi digunakan untuk mengukukur efektivitas program. Dalam hal ini mengukur kemampuan penyelenggara program dalam melakukan sosialisasi 
kepada sasaran tentang program yang akan dilaksanakan. Hasil penelitian menunjukkan bahwa kemampuan Pemerintah Kabupaten Gunungkidul dalam melakukan sosialisasi program Bantuan Keuangan Khusus (BKK) dinilai baik. Hal ini dapat diindikasikan dengan tingginya pengetahuan RTS terhadap program BKK, dan dalam proses sosialisasi BKK Pemerintah Kabupaten Gunungkidul tidak mendapatkan kendala yang berarti.

Kemampuan pemerintah Kabupaten Gunungkidul dalam melakukan proses sosialisasi Bantuan Keuangan Khusus (BKK), dapat disimpulkan menjadi 3 hal. Pertama, pemerintah Kabupaten Gunungkidul telah menyiapkan perangkat hukum dan SKPD pelaksana, perangkat hukum yang digunakan berupa PERBUP, sementara SKPD pelaksana sosialisasi adalah BP2KP Gunungkidul, Kecamatan dan Kelurahan/Desa. Kedua, pemerintah Kabupaten Gunungkidul menjalankan proses sosialisasi sesuai dengan mekanisme yang sudah ditetapkan sebelumnya, yaitu sosialisasi di tingkat Kabupaten dan sosialisasi di tingkat Desa. Ketiga, tingkat pengetahuan Rumah Tangga Sasaran (RTS) tentang program BKK cukup tinggi, hal ini mengindikasikan bahwa sosialisasi yang dilakukan oleh Pemerintah Kabupaten Gunungkidul cukup berhasil.

\section{Ketepatan Sasaran}

Ketepatan sasaran merupakan salah satu indikator utama dari program yang bersifat disalurkan seperti program pengentasan kemiskinan. Indikator ketepatan terhadap sasaran merupakan tolak ukur pertama terhadap penyelesain persoalan yang ada di lapangan, apabila program tersebut tidak tepat sasaran maka permasalahan 
3.1 tersebut akan tetap berjalan. Dalam kaitannya dengan ketepatan sasaran penerima dana Bantuan Keuangan Khusus (BKK) di Kabupaten Gunungkidul, jumlah Rumah Tangga Sasaran (RTS) telah ditetapkan oleh Pemerintah Provinsi Daerah Istimewa Yogyakarta yaitu sebanyak 1.615 RTS pada Tahun 2013 dan 8.355 RTS pada Tahun 2014 (BAPPEDA DIY, 2014).

Pada Tahun 2014 terdapat 310 RTS yang telah ditetapkan sebelumnya sebagai penerima dana program BKK di Kabupaten Gunungkidul tidak lolos verifikasi. Rinciannya adalah 9 orang telah meninggal dunia, 111 orang telah pindah alamat, 187 orang telah menerima sebelumnya dan 3 orang tidak bersedia menerima. Untuk mengganti RTS yang tidak lolos verifikasi, maka Pemerintah Daerah Kabupaten Gunungkidul melakukan verifikasi ulang untuk mendapatkan kuota RTS sesuai dengan yang telah ditetapkan oleh Provinsi yaitu sebanyak 8.355 RTS.Program Bantuan Keuangan Khusus (BKK) merupakan program yang dicanangkan oleh pemerintah Daerah Istimewa Yogyakarta dalam upaya pengentasan kemiskinan. Merujuk kepada hal tersebut Pemerintah Kabupaten Gunungkidul dalam hal ini hanya mengikuti dan melaksanakan program sesuai dengan arahan dan mekanisme yang ditetapkan oleh Pemerintah Provinsi DIY. Dalam hal ini penetapan Rumah Tangga Sasaran (RTS) merupakan wewenang mutlak Pemprov DIY, Pemkab Gunungkidul hanya menyediakan data Kemiskinan, sementara dalam hal penetapan RTS penerima dana bantuan Pemkab Gunungkidul tidak terlibat sama sekali. 
Jumlah RTS penerima bantuan program BKK pada Tahun 2013 berjumlah 16.615 RTS dengan persentase 11,19 persen dari total jumlah penduduk miskin di Gunungkidul. Sementara pada Tahun 2014 angka ini mengalami penurunan menjadi 5,63 persen dari total jumlah penduduk miskin di Kabupaten Gunungkidul (BPS Gunung Kidul 2011-2015).Budiani (2007:53) menyebutkan ketepatan sasaran program adalah sejauhmana peserta program tepat dengan sasaran yang sudah ditentukan sebelumnya.

\section{Gambar V.2}

\section{Ketepatan Sasaran}

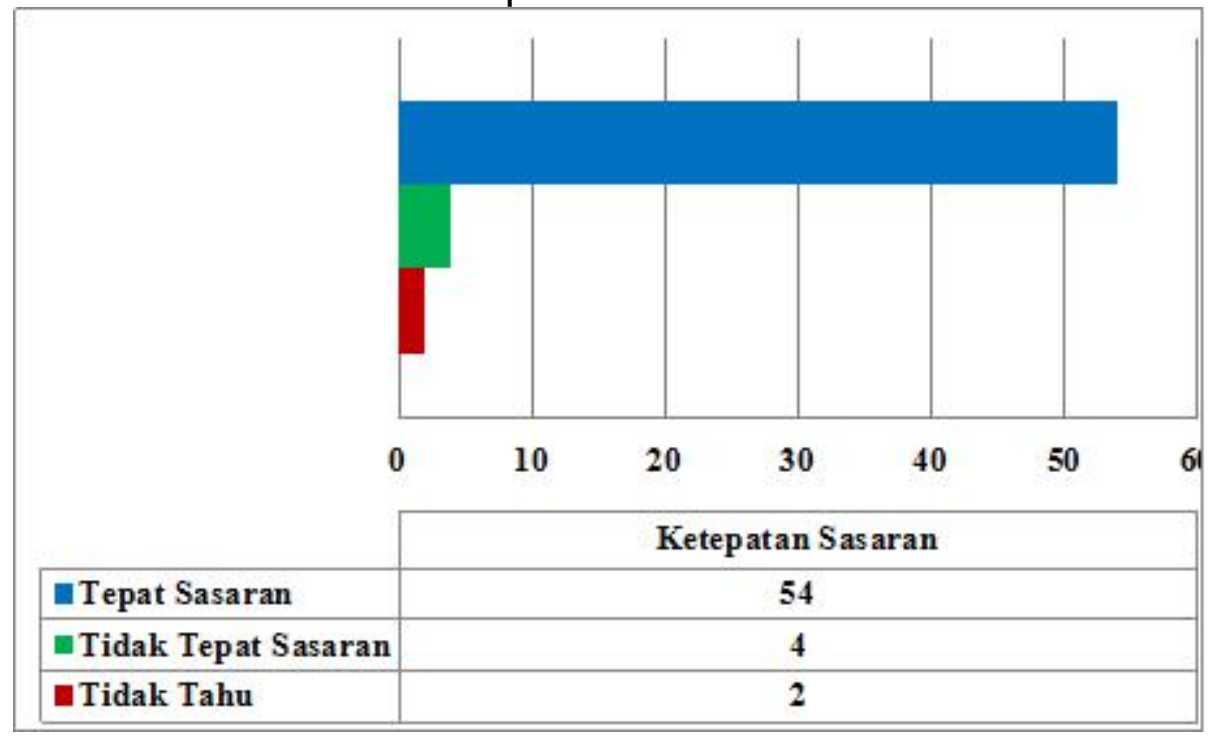

Merujuk pada gambar diatas, dari 60 orang yang menjadi narasumber 54 orang mengakui bahwa program Bantuan Keuangan Khusus (BKK) sudah tepat sasaran, 4 orang mengatakan tidak tepat sasaran, dan 2 narasumber mengatakan tidak tahu. Menurut Campbel (1989) pengkukuran efektifitas dapat dilakukan dengan menilai keberhasilan sasaran. Penetapan sasaran atau Rumah Tangga Sasaran 


\section{4. (RTS) dalam program bantuan keuangan khusus di Kabupaten} Gunungkidul oleh Pemerintah Provinsi DIY, merujuk pada hasil Sussenas 2011 tentang jumlah angka miskin di Kabupaten Gunungkidul. Program BKK adalah program Pemerintah Provinsi DIY dalam mengentaskan kemiskinan, secara garis besar program ini ditujukan untuk mengurangi angka kemiskinan di DIY dan di Gunungkidul pada khususnya, dan jumlah rumah tangga sasaran telah ditetapkan sesuai dengan kuota per Kabupaten/Kota.

Penetapan Rumah Tangga Sasaran (RTS) dalam Program Bantuan Keuangan Khusus (BKK) di Kabupaten Gunungkidul, secara garis besar dipilih berdasarkan tingkat kemiskinan kelompok I. Dalam laporan BPS yang dimaksud dengan kelompok desil I yaitu rumah tangga yang termasuk dalam 10 persen rumah tangga dengan tingkat kesejahteraan terendah di Indonesia, atau yang biasanya disebut rumah tangga miskin. Berdasarkan penjelasan diatas dapat dinilai bahwa pemilihan Rumah Tangga Sasaran (RTS) dalam program Bantuan Keuangan Khusus (BKK) secara umum sudah tepat, sesuai dengan tingkat kemiskinan kelompok yang menjadi sasaran program.

\section{Ketepatan Jumlah}

Indikator ketepatan jumlah dalam pelaksanaan program sangat berperan penting untuk mengetahui ada atau tidaknya penyelewengan dan ketidaksesuaian antara jumlah dana yang telah ditetapkan dengan jumlah dana yang diterima oleh penerima dana bantuan. Menurut Effendy (2003) Menurut efektivitas adalah komunikasi yang prosesnya mencapai tujuan yang direncanakan sesuai dengan biaya yang dianggarkan, waktu yang ditetapkan dan jumlah personil yang 
ditentukan. Dalam kaitannya dengan penelitian ini Jumlah dana yang diterima oleh Rumah Tangga Sasaran (RTS) dalam program Bantuan Keuangan Khusus (BKK) di DIY telah ditetapkan sebesar $\mathrm{Rp}$ 1.000.000, (Satu Juta Rupiah) berdasarkan Keputusan Gubernur Nomor 205/KEP/2013.

Pada Tahun 2013 Kabupaten Gunungkidul menerima dana bantuan yang lebih besar dibanding Kabupaten/Kota lain yaitu sebesar 16,6 Milyar rupiah. Jumlah dana bantuan yang diterima Kabupaten Gunungkidul pada Tahun 2014 mengalami penurunan yang signifikan, yaitu hanya sebesar 8,35 Milyar rupiah. Angka ini menyusut separuh dibandingkan dengan dana yang diterima Gunungkidul pada Tahun 2013.

Gambar V.3

Ketepatan Jumlah

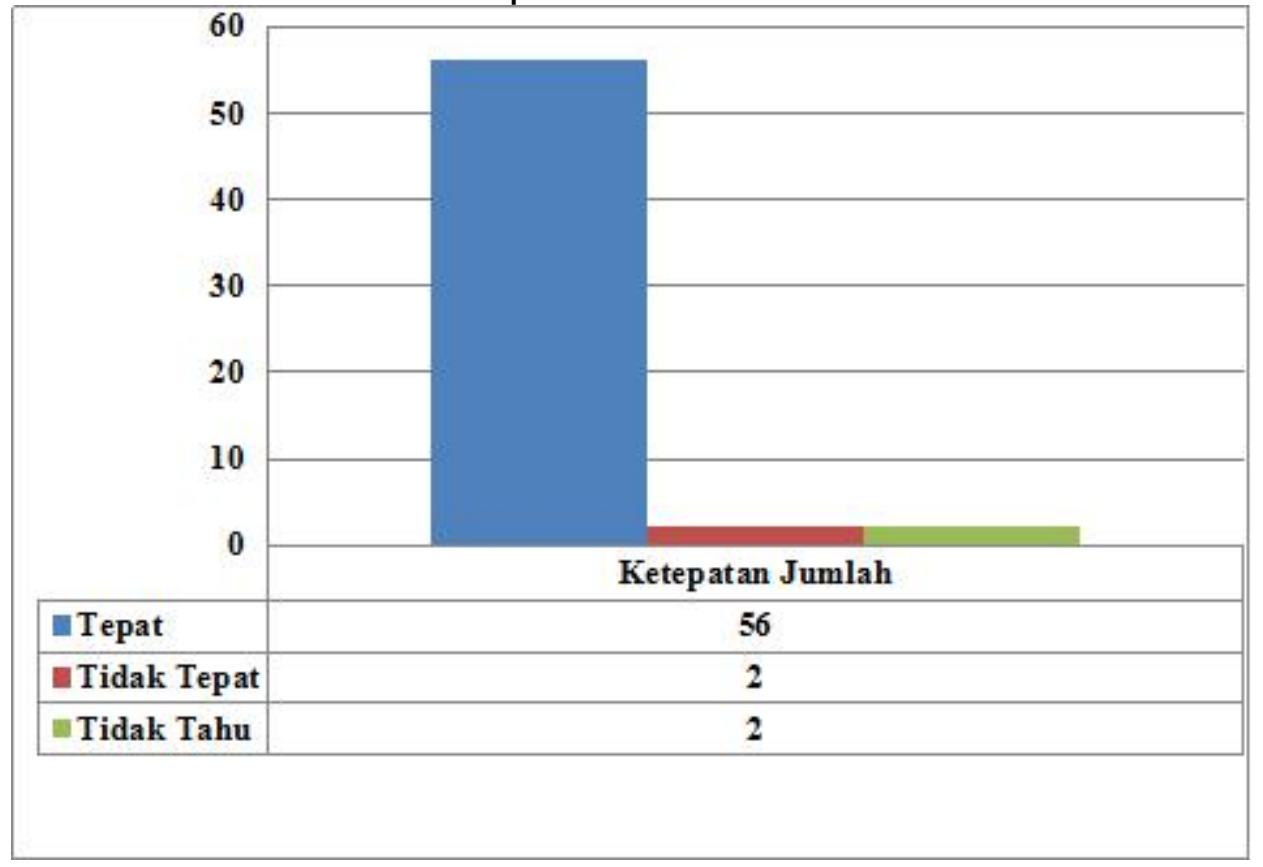


Dari 60 orang yang menjadi narasumber penelitian 58 orang mengakui menerima dana dengan utuh yaitu sebesar Rp. 1.000.000,-, sementara 2 narasumber mengaku tidak mendapatkan Rp 1.000.000, melainkan Rp 900.000,-. Dan 950.000,-, Untuk 2 orang narasumber tersebut mengaku kalau dana yang dicairkan dari pihak Pemerintah Daerah sebenarnya utuh dan sesuai dengan nominal yang telah ditetapkan, akan tetapi anggota kelompoknya bersepakat untuk menyisihkan sebagai dana kas atau dana cadangan yang diperuntukkan untuk anggota dikemudian hari, apabila terdapat kebutuhan yang bersifat mendadak dalam menjalankan usaha.

\section{Ketepatan Administrasi}

Ketepatan administrasi dalam mengukur efektivitas sebuah program, dapat diartikan sebagai ketepatan mekanisme atau tata cara tertulis yang harus ditempuh dalam pelaksanaan sebuah program. Ketepatan administrasi merupakan variabel yang dapat mengukur apakah program tersebut dijalankan sesuai dengan mekanisme yang telah ditetapkan sebelumnya atau tidak. Dengan kata lain ketepatan administrasi merupakan tolak ukur terhadap adanya kepatuhan terhadap mekanisme yang telah ditentukan sebelumnya.

Untuk memperlancar jalannya mekanisme maka dibentuklah kelompok, RTS masih harus melalui 2 tahapan lagi sebelum dana BKK dicairkan, 2 tahapan tersebut meliputi:

1. Penyusunan Usulan Kegiatan Kelompok

1) setelah kelompok terbentuk, dilanjutkan dengan proses penyusunan usulan rencana kegiatan kelompok. 
2) usulan rencana kegiatan kelompok bisa merupakan kegiatan usaha bersama maupun individu.

3) pemerintah Desa bersama Pendamping memfasilitasi tata cara penyusunan usulan rencana kegiatan kelompok, selanjutnya melakukan verifikasi atas kelayakan usulan rencana kegiatan kelompok yang telah disusun oleh kelompok.

4) usulan rencana kegiatan kelompok yang telah tersusun, selanjutnya disampaikan secara berjenjang kepada Kepala Desa, Camat dan BAPPEDA untuk dilakukan verifikasi dan pengesahan.

5) Usulan rencana kegiatan kelompok dilampiri dengan daftar anggota kelompok dan bukti-bukti lain yang diperlukan.

2. Pembukaan Rekening Kelompok

Setelah terbentuk kelompok RTS, kelompok calon penerima bantuan membuka rekening Bank atas nama Kelompok di Bank yang ditunjuk, dengan syarat pembukaan rekening sebagai berikut:

1) foto copy KTP/SIM Ketua dan Bendahara kelompok.

2) foto copy struktur organisasi Kelompok yang diketahui Kepala Desa yang

dibubuhi tanda tangan Kepala Desa dan stempel Kepala Desa.

3) mengisi aplikasi pembukaan rekening tabungan

Mekanisme pencairan dan penyaluran dana bantuan keuangan khusus (BKK) berdasarkan hasil wawancara yang dilakukan penulis terhadap 60 orang narasumber yang menerima dana program BKK di Gunungkidul memiliki jawaban yang beragam. Syarat yang dibutuhkan untuk mecairkan dana BKK yakni harus sudah terbentuk 
360 kelompok dengan kepengurusan yang jelas seperti adanya Ketua, Bendahara dan Sekertaris. Kemudian kelompok tersebut harus membuat proposal, serta cap kelompok, kemudian membuka rekening Bank untuk menstransfer dana bantuan keuangan khusus (BKK). Dalam kaitannya dengan hasil penelitian ini dalam hal ketepatan administrasi pencairan dana bantuan keuangan khusus dapat dilihat pada gambar dibawah ini:

\section{Gambar V.5}

Ketepatan Administrasi

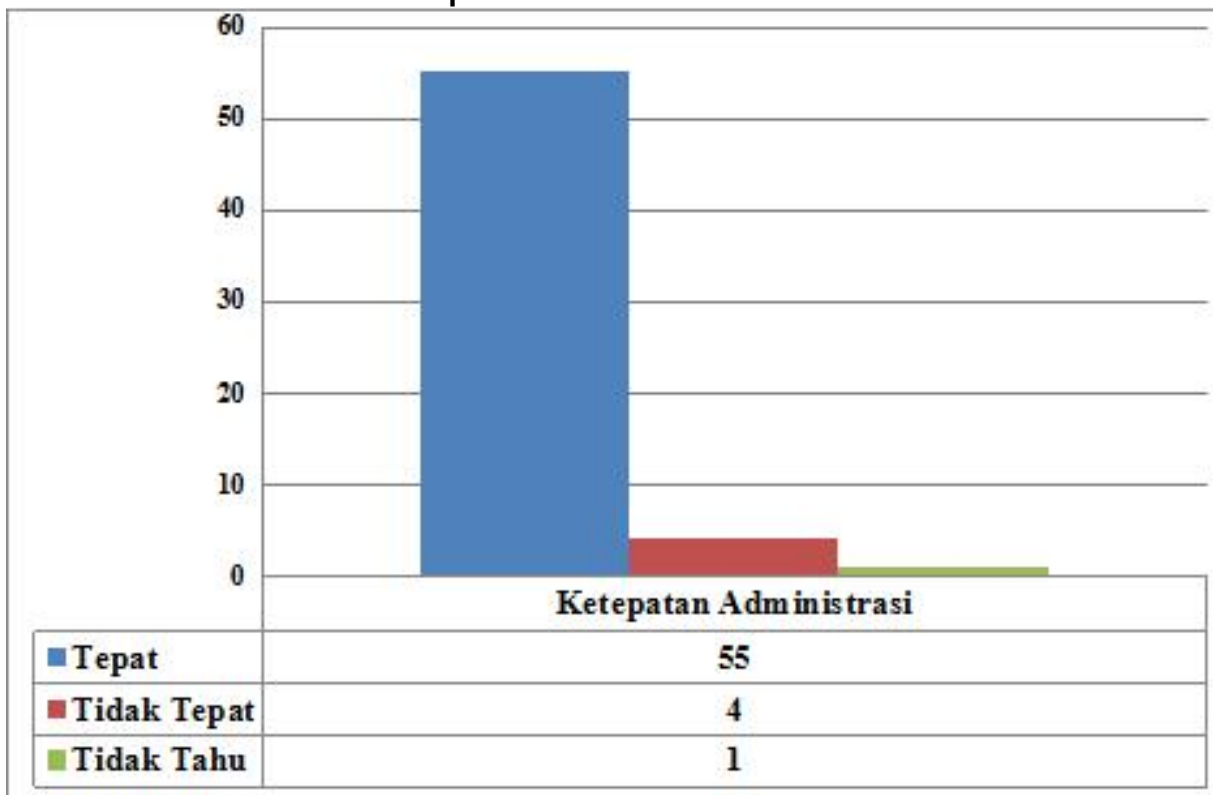

Dari gambar diatas dapat dilihat bahwa 55 orang dari 60 narasumber mengakui bahwa mekanisme pencairan dana sudah sesuai dengan ketentuan yang ditetapkan, sementara 5 orang narasumber mengatakan bahwa mekanisme pencairan dana program tidak tepat administrasi. Narasumber yang merasa mekanisme pencairan dana 
bantuan keuangan khusus (BKK) tidak tepat administrasi mengaku tidak diminta membuat proposal dan tidak dimintai persyaratan administrasi lainnya, yang diminta hanya meliputi KTP dan Kartu Keluarga Ketua dan Bendahara kelompok sebagai syarat untuk membuka rekening. Sekalipun ada 5 RTS yang mengatakan bahwa proses pencairan BKK tidak tepat administrasi, bukan berarti mereka keberatan akan tetapi mereka mengakui bahwa pengurusan administrasi telah dilakukan oleh pihak kelurahan dan mereka hanya mengumpulkan syarat-syarat yang dibutuhkan kepada pihak kelurahan/Desa.

\section{Ketepatan Waktu}

Indikator ketepatan waktu dalam mengukur efektifitas program yang bersifat distributif sangat diperlukan, terlebih lagi dana distributif tersebut berbentuk dana bantuan. Indikator ketepatan waktu bisa dijadikan sebagai patokan ada tidaknya kepatuhan terhadap disiplin waktu pelaksanaan program. Apabila proses pencairan dan pelaksanaan program tersebut berjalan sesuai dengan waktu yang ditetapkan maka bisa dipastikan program tersebut akan lebih cepat mencapai sasaran yang dituju. Program dana BKK merupakan program pemerintah Daerah Istimewa Yogyakarta, dengan mekanisme dan anggaran yang telah ditetapkan oleh PEMPROV DIY. Sebelum dana BKK sampai ketangan RTS Pemerintah Provinsi DIY terlebih dahulu mentransfer dana ke DPPKAD Gunungkidul, kemudian DPPKAD mentransfer lagi ke Bank BPD Gunungkidul ,baru kemudian dana diterima oleh RTS. 


\section{2}

\section{Gambar V.7}

\section{Ketepatan Waktu}

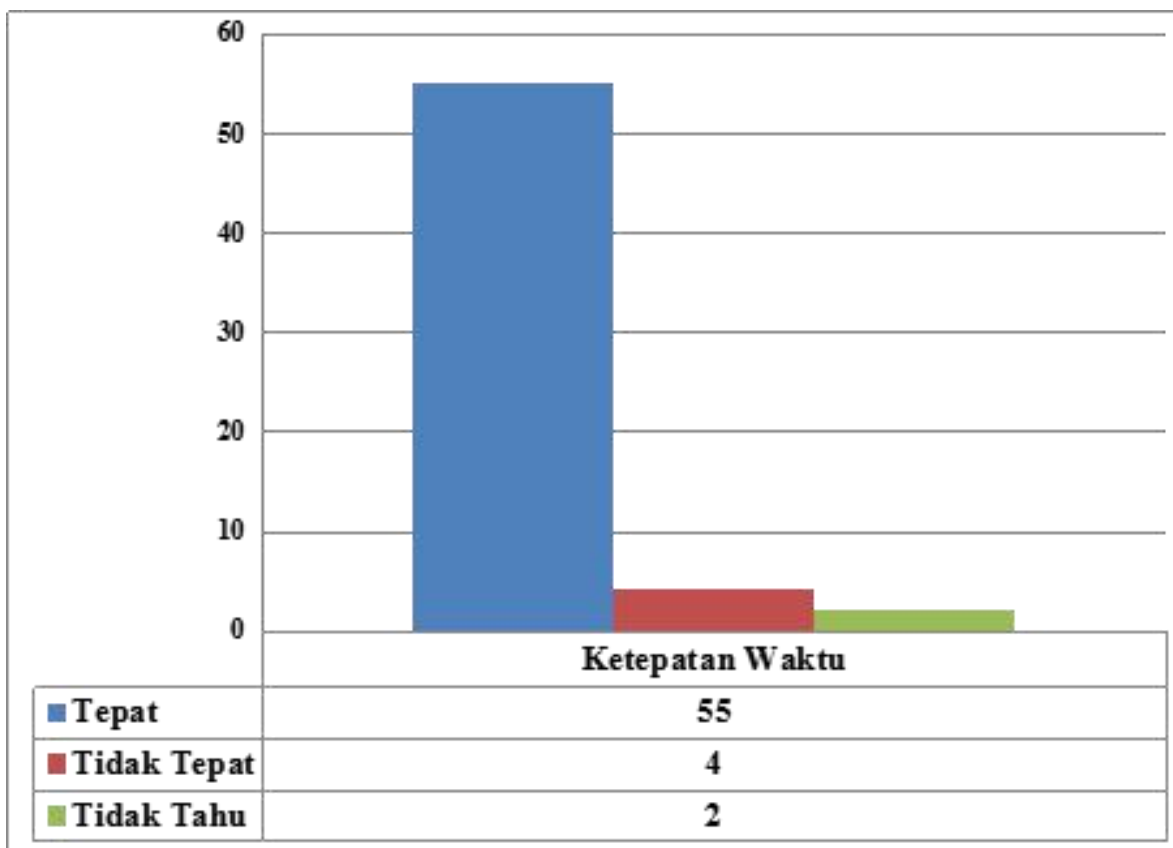

Berdasarkan hasil wawancara dilapangan, 60 RTS yang telah menjadi responden menyatakan dana bantuan sudah cair semua dan mereka telah memanfaatkan bantuan tersebut. Dari 60 orang yang menjadi narasumber, 55 orang mengatakan bahwa pencairan dana BKK tepat waktu, 3 orang narasumber mengatakan tidak tepat waktu, dan sisa 2 orang lagi menjawab tidak tahu. Tiga orang narasumber yang mengaku tidak tepat waktu mengaku bahwa pencairan dana BKK 
dilakukan tidak sesuai dengan tanggal yang ditetapkan, sementara 2 narasumber yang mengaku tidak tahu beralasan bahwa proses pencairan dana sudah diurus oleh ketua dan sekretaris kelompok dan mereka tidak terlibat sama sekali.

Pelaksanaan program bantuan keuangan khusus (BKK) di Kabupaten Gunungkidul telah melalui berbagai tahapan.Tahapan pertama ditingkat provinsi terkait dengan penetapan program, penetapan rumah tangga sasaran (RTS) dan penetapan anggaran.Sementara tahapan di tingkat Kabupaten terkait dengan sosialisasi, verifikasi dan pelaksanaan. Tahapan-tahapan tersebut telah di tetapkan dalam APBD Provinsi DIY maupun APBD Kabupaten Gunungkidul, yaitu APBD Tahun 2013 dan APBD Tahun 2014.

Berdasarkan data-data yang diperoleh penulis program bantuan keuangan (BKK) di Kabupaten Gunungkidul secara umum telah terlaksana sesuai dengan waktu yang telah ditetapkan sebelumnya. Pada Tahun 2013 pencairan dana program BKK ditetapkan pada bulan juni 2013, dan dalam proses pelaksanaanya dana BKK memang dicairkan pada bulan tersebut. Sementara itu pencairan dana program BKK 2014 ditetapkan pada bulan Oktober 2014 dan dalam pelaksanaanya adanya kesesuaian antara waktu yang ditetapkan sebelumnya dengan waktu pelaksanaanya.

\section{Ketepatan Pengguna}

Kaitannya dengan program bantuan keuangan khusus (BKK) Kabupaten Gunungkidul ada syarat-syarat peruntukan yang harus dipenuhi rumah tangga sasaran (RTS) sebagai pihak yang menerima 
36. dana bantuan program bantuan keuangan khusus (BKK) yang meliputi:

1) pengembangan usaha sesuai dengan bidang usaha yang digeluti.

2) mengembangkan usaha baru,baik dengan cara bersama-sama sesuai dengan kesepakatan kelompok atau usaha yang direncanakan kelompok maupun usaha yang bersifat individu. Adapun Usaha yang dapat dikembangkan dalam BKK dengan memanfaatkan potensi sumber daya lokal antara lain;

1) usaha primer pertanian produktif dan kreatif,yang meliputi tanaman pangan,peternakan,perikanan dan perkebunan.

2) usaha yang bersifat olahan/home industri,dan

3) usaha jasa produktif.

Kegiatan Yang Tidak Boleh Dibiayai Kegiatan yang tidak boleh dibiayai dengan dana BKK, adalah sebagai berikut:

1) kegiatan yang berkaitan dengan politik praktis (kampanye, demonstrasi, dll)

2) deposito atau simpanan yang berkaitan dengan usaha memupuk bunga bank.

3) sebagai jaminan atau agunan atau garansi, baik yang berhubungan dengan

lembaga keuangan dan perbankan maupun pihak ketiga lainnya.

4) pembangunan/perbaikan rumah

5) pembelian alat transportasi maupun elektronik yang bersifat individual 
6) kebutuhan dasar hidup meliputi pangan,sandang,papan.

7) pemenuhan kebutuhan pendidikan dan kesehatan.

8) pemenuhan kebutuhan sosial (sumbangan,rasulan,dll).

9) usaha yang bertentangan dengan hukum,norma-norma sosial dan agama.

Ketepatan penggunaan dana bantuan keuangan khusus (BKK) di Kabupaten Gunungkidul, dapat dikategorikan menjadi 3 hal:

1) dana Bantuan Keuangan Khusus (BKK) digunakan untuk membuat atau memulai usaha baru,

2) dana Bantuan Keuangan Khusus (BKK) digunakan untuk membesarkan atau mengembangkan usaha yang sudah ada sebelumnya.

3) dana Bantuan Keuangan Khusus (BKK) digunakan untuk meneruskan usaha yang sudah ada sebelumnya namun gagal atau mati.

\section{Gambar V.8}

Ketepatan Penggunaan

\begin{tabular}{|l|l|l|l|l|l|l|l||}
\hline & & & & & & & \\
\end{tabular}




\section{Merujuk pada gambar diatas dari 60 orang yang menjadi} narasumber penelitian 59 orang mengakui bahwa dana bantuan keuangan khusus (BKK) dimanfaatkan dengan tepat sementara 1 orang mengaku tidak tepat. Narasumber yang mengatakan penggunaanya tepat mengakui pemilihan usaha baru, meneruskan usaha yang sudah pernah ada tapi gagal atau mati, maupun mengembangkan atau membesarkan usaha yang sudah ada, memberikan dampak yang positif terhadap produktifitas dan pendapatan mereka. Sementara 1 orang narasumber menyebutkan bahwa dana bantuan keuangan khusus tidak digunakan dengan tepat karena adanya arahan dari kelurahan untuk menggunakannya untuk hal tertentu yang tidak sesuai dengan kemampuan si penerima dana bantuan, dalam hal ini si penerima bantuan diarahkan untuk membeli bibit tanaman sementara profesinya sehari-hari adalah pedagang keliling.

\section{Faktor-Faktor yang Mempengaruhi}

Dari penjelasan diatas dapat diketahui bahwa secara umum pelaksanaan pelaksanaan program Bantuan Keuangan Khusus (BKK) di Kabupaten Gunungkidul dapat dikategorikan menjadi 2 hal:

1) merujuk pada teori dan mekanisme pelaksanaan maka dapat dikatakan pelaksanaan program bantuan keuangan khusus di Kabupaten Gunungkidul sudah sesuai dengan teori dan mekanisme yang ada.

2) melihat fakta dilapangan dan data yang dikeluarkan oleh Badan Pusat Statistik (BPS) bahwa program bantuan keuangan 
khusus tidak memiliki pengaruh yang signifikan terhadap menurunkan angka kemiskinan di Kabupaten Gunungkidul.

Ada tiga kriteria yang dianggap sesuai dengan keadaan di lapangan dalam hal pelaksanaan program BKK di Kabupaten Gunungkidul, yang meliputi:

1) Masalah Stabilitas Kriteria

Artinya bahwa banyak kriteria evaluasi yang digunakan ternyata relatif tidak stabil setelah beberapa waktu.Yaitu kriteria yang dipakai untuk mengukur efektivitas pada suatu waktu mungkin tidak tepat lagi atau menyesatkan pada waktu berikutnya.Kriteria tersebut berubah-ubah tergantung pada permintaan, kepentingan dan tekanantekanan ekstern.Dalam kaitannya dengan penelitian ini yang dimaksud dengan kriteria adalah, kriteria kemiskinan dalam menentukan rumah tangga sasaran (RTS).Masalah stabilitas kriteria sudah terlihat ketika terdapat ketidaksesuaian antara data yang dimiliki oleh Pemerintah Provinsi DIY dengan data yang dimiliki oleh Badan Pusat Statistik DIY soal angka kemiskinan di DIY.

Masalah ketidaksinkronan data tersebut dapat dikatakan memiliki andil yang sangat besar terhadap kegagalan program BKK dalam mengurangi angka kemiskinan di Kabupaten Gunungkidul.Untuk memperbaiki data kemiskinan di Kabupaten Gunungkidul maka Gubernur DIY memerintahkan agar dilakukan pendataan ulang terhadap penduduk miskin di DIY didata.Pendataan penduduk miskin ini melibatkan SKPD, TNI dan lembaga swadaya masyarakat (LSM).Pendataan dilakukan dengan mekanisme dari pintu 
368 ke pintu, dengan metode ini diharapkan diperoleh data yang valid mengenai angka kemiskinan di Kabupaten Gunungkidul.

\section{2) Masalah Perspektif Waktu}

Pengukuran angka kemiskinan disuatu daerah dilakukan BPS menurut Tahun anggaran.Program BKK pada Tahun 2013 dilaksanakan pada bulan Juni 2013 sementara BPS mengeluarkan data kemiskinan pada bulan September 2014.Sementara itu program BKK Tahun 2014 dilaksanakan pada bulan Oktober 2014 dan BPS merilis angka kemiskinan di bulan September 2015.Melihat pada fakta tersebut penilaian dilakukan hanya berselang satu tahun setelah program berjalan. Mengingat nominal bantuan program BKK hanya berjumlah 1 jt Rupiah, maka dibutuhkan proses dan waktu yang lama apakah bantuan tersebut berpengaruh terhadap penurunan angka kemiskinan di Kabupaten Gunungkidul. Sebagai contoh: Apabila RTS atau kelompok menggunakan dana BKK untuk membeli bibit ternak maka diperlukan waktu sampai ternak tersebut berproduksi atau bisa dijual kembali, begitu juga dengan RTS yang menggunakan dana BKK untuk membeli bibit tanaman.

3) Masalah tingkat analisis

Menurut Badan Pusat Statistik (2014) penetapan perhitungan garis kemiskinan dalam masyarakat adalah masyarakat yang berpenghasilan dibawah US\$ 1,7 per orang per hari. Untuk kebutuhan minimum makanan digunakan patokan 2.100 kilo kalori per kapita per hari.Sedangkan untuk pengeluaran kebutuhan 
minimum bukan makanan meliputi pengeluaran untuk perumahan, pendidikan, dan kesehatan.

Realita dilapangan membuktikan bahwa masyarakat Gunungkidul adalah masyarakat gemar menyimpan dan menabung. Disamping itu masyarakat Gunungkidul yang mayoritas memiliki mata pencaharian sebagai petani dalam memenuhi kebutuhan sehari-hari lebih banyak mengandalkan tanah garapannya sendiri daripada membeli.Dari fakta-fakta tersebut maka tidak adil jika pengukuran angka kemiskinan hanya merujuk kepada standar bank dunia, dengan hanya menghitung pendapatan dan pengeluaran masyarakat untuk kebutuhan minimum sehari-hari.

Dalam hal ini kesimpulan bahwa Pemerintah Provinsi DIY dan Pemerintah Kabupaten Gunungkidul gagal dalam mengentaskan kemiskinan tidak sepenuhnya benar. Hal ini disebabkan adanya pola prilaku individu di dalam Masyarakat Gunungkidul yang secara tidak langsung mempengaruhi tingkat keberhasilan Pemprov DIY dan Pemkab Gunungkidul sebagai organisasi dalam mengukur efektiv atau tidaknya program BKK di Kabupaten Gunungkidul.

\section{KESIMPULAN}

Berdasarkan hasil penelitian terhadap efektivitas Bantuan Keuangan Khusus (BKK) di Kabupaten Gunungkidul Tahun 2013. 2014, maka hasil penelitian ini dapat disimpulkan sebagai berikut.

1. Sosialisasi

Sosialisasi yang dilakukan oleh pemerintah Kabupaten Gunungkidul terhadap Rumah Tangga Sasaran (RTS) penerima dana Bantuan 
361 Keuangan Khusus (BKK) cukup berhasil. Hal ini diindikasikan dengan tingginya pengetahuan RTS terhadap program BKK dan minimnya kendala yang dihadapi dalam proses sosialisasi.

\section{Ketepatan Sasaran}

Pemilihan Rumah Tangga Sasaran (RTS) oleh pemerintah Provinsi DIY dan hasil verifikasi Pemerintah Kabupaten Gunungkidul terhadap rumah tangga sasaran cukup baik. Hal ini diindikasikan dengan rendahnya kesalahan dalam pemilihan RTS dan minimnya kendala yang dihadapi pada saat proses verifikasi.

3. Ketepatan Jumlah

Ketepan jumlah yang diterima oleh Rumah Tangga Sasaran (RTS) dengan nominal yang ditetapkan sebelumnya dalam proses pencairan dana BKK di Kabupaten Gunungkidul cukup baik. Hal ini dibuktikan dengan adanya kesesuaian antara dana yang diterima RTS dengan dana yang telah ditetapkan sebelumnya yaitu sebesar Rp, 1.000.000,00 per RTS.

\section{Ketepatan Administrasi}

Ketepatan administrasi dalam pelaksanaan program bantuan keuangan khusus di Kabupaten Gunungkidul dapat dinilai baik. Hal ini dapat dibuktikan dengan adanya kepatuhan terhadap proses administrasi sesuai dengan yang tertuang dalam Peraturan Bupati Gunungkidul Nomor 5 Tahun 2014 Tentang Petunjuk Teknis Penyaluran Bantuan Keuangan Khusus Dalam Upaya Pengentasan Kemiskinan Tahun Anggaran 2014. 
5. Ketepatan Waktu

Ketepatan waktu dalam pelaksanaan program bantuan keuangan khusus di Kabupaten Gunungkidul secara umum berjalan baik. Walaupun ada sedikit kendala dalam proses verifikasi namun proses pencairan dana BKK berjalan sesuai dengan waktu yang ditetapkan, yaitu bulan Juni Tahun 2013 dan Bulan Oktober Tahun 2014.

6. Ketepatan Penggunaan

Ketepatan penggunaan dana bantuan program BKK di Kabupaten Gunungkidul secara umum sudah sesuai dengan petunjuk pelaksanaan program. Akan tetapi program Bantuan Keuangan Khusus (BKK) di Kabupaten Gunungkidul hanya berhasil mengurangi angka kemiskinan sebesar 1,02 persen pada tahun 2013 dan 0,87 persen pada Tahun 2014. Dari angka tersebut dapat dikatakan bahwa program BKK di Kabupaten Gunungkidul tidak berhasil atau gagal, karena target yang telah ditetapkan sebelumnya adalah sebesar 2 persen.

\section{DAFTAR PUSTAKA}

Badan Pusat Statistik DIY, DIY Dalam Angka 20 I4, Yogyakarta: Penerbit BPS DIY, 2014.

Budiani, Ni Wayan, Efektivitas Program Penanggulangan Pengangguran Karang Taruna "Eka Taruna Bhakti" Desa Sumerta Kelod Kecamatan Denpasar Timur Kota Denpasar, Denpasar: Jurnal Ekonomi dan Sosial INPUT. Volume 2 No. I, 2007.

Campbell, Riset dalam Efektivitas Organisasi, Terjemahan Sahat Simamora. Jakarta: Erlangga, 1989.

Effendy, Onong, Uchjana, IImu, Teori dan Filsafat Komunikasi, Bandung: Citra Aditya Bakti Bandung, 2003. 
362 Handayaningrat, Soewarno, Azas-azas Organisasi Manajemen, Jakarta: CV Mas Agung, 1995.

Kuncoro, Mudrajad, Ekonomi Pembangunan Teori, Masalah, dan Kebijakan, Yogyakarta: UPP AM P YKPN, 2000.

Nasution, Zulkarimein, Prinsip-prinsip Komunikasi untuk Penyuluhan, Jakarta: Fakultas Ekonomi Universitas Indonesia, 1990.

Peraturan Bupati Gunungkidul Nomor 5 Tahun 2014 Tentang Petunjuk Teknis Penyaluran Bantuan Keuangan Khusus Dalam Upaya Pengentasan Kemiskinan Tahun Anggaran 2014 